\title{
Distribution of the Black-footed Albatross (Diomedea nigripes) in the north Pacific Ocean
}

Tsukasa Nakamura

\section{Introduction}

A number of ornithologists have made observations of the Black-footed Albatross (Diomedea nigripes) in the Pacific Waters. Miller (1940) reported its general status in the North West Pacific, and also (1942) made some marking experiments. Yocom (1947) worked in the North Pacific and Thompson (1951) between San Francisco and Hawaii. Arnold (1948), Kuroda, Jr. (1955, 1960a, 1960b), Hamilton (1958) reported oceanic distribution of the Black-foots in several areas of the North Pacific. They discussed the factors acting upon concetrations of the Albatrosses. Wilhoft (1961) recently studied correlation between water temperature and numbers of Black-foots based on his own results and those of other workers.

I had opportunities to cross the North Pacific both in August 1959 and March 1961. My first trip of 1959 was from Yokohama to San Francisco direct course and

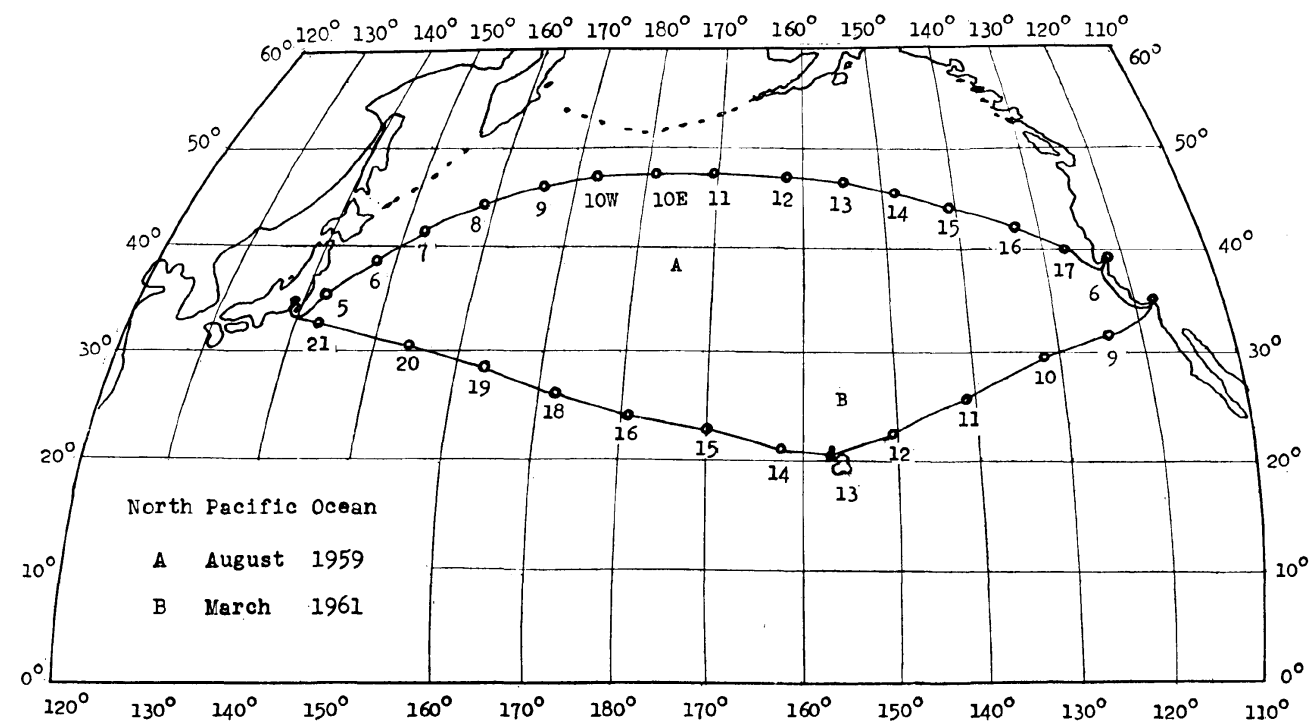

Fig. 1. Daily positions of boats during two crossings of the Pacific Ocean.

* Biological Dept., Yamanashi University, Kofu, Yamanashi Pref., Japan. 
returning trip in 1961 was from San Francisco to Yokohama via Los Angels and Honolulu (Fig. 1). This paper reports the distributional data of the Black-foots obtained during the above sea voyages and some meteorological factors which may affect their distributions are discussed.

\section{General observation}

Observations were made 10 to 15 minutes every day between 8 AM and 12 PM and additional observations were made on the returning trip at 16 PM. Number of Albatrosses within about 500 meters distance was counted by means of a binocular $(9 \times 32)$. At the same time, meteorological data issued from the boat were recorded.

The weather was very rough almost every day in the first trip. On the other hand, it was very calm most of the day through the returning trip. The boat of the first trip was approximately 7,000 tons freighter which had nearly constant speed of 13 knots, whereas on the returning trip, the boat was about 20,000 tons passenger boat with an average speed of 19 knots.

The Black-foots were first observed on August 7, three days after sailing from Yokohama. Five Black-foots were already following our boat in early morning, and one Laysan Albatross was noticed at noon. As Miller (1940, '42) stated Black-foots have scavenging food habit, I often observed that whenever crews overthrown the remained food overboad, the birds flew to it for scavenging. Apparently the Albatrosses would follow for food. With respect to the night flight, Yocom (1947) has often seen them fly past the ship on moon light nights, but I can present only one occasion which was seen in the returning trip near Hawaiian Island. Among threeperiod observations during the trip in 1961, total numbers of Black-foots at noon were considerably low in comparison with the observations both at $8 \mathrm{PM}$ and 16 PM. Among the Black-foots, white-rumped individuals were observed sometimes during our trips. It is still in argument among some of Japanese ornithologists whether the white-rumped Black-foots are young or adult. It seems to me that, they would fall inı adult because of being slightly larger in size than other Blackfoots. These individuals were found more in the eastern side of the Pacific Ocean.

The numbers of the Laysan Albatross observed during the trips were also added on Table 3 and 4. However, numbers observed are very few compared with Blackfoots, since this species does not make any small group. Consequently only one individual was in sight and passed the boat but without turning to it any one time during our trips. Wolhoft (1961) observed only one individual during his 36 days trip in the Pacific. Whereas, Hamilton (1958) observed 10 individuals of the Laysan Albatrosses on one occasion.

It seems in general that each Black-foots did not follow the boat more than a few hours. This was comfirmed by continuous and every hour observations which 
Table 1. Noon positions and noon air and water temperatures, 1959

\begin{tabular}{|c|c|c|c|c|c|c|c|c|c|}
\hline \multicolumn{2}{|l|}{ Date } & \multicolumn{2}{|c|}{$\begin{array}{c}\text { Noon position } \\
\text { Latitude } \quad \text { Longitude }\end{array}$} & \multicolumn{2}{|c|}{$\begin{array}{l}\text { Air Water } \\
\text { Centigrade }\end{array}$} & $\underset{\%}{\text { Humidity }}$ & Wave & Wind & Weather \\
\hline August & 5 & $36^{\circ} 38^{\prime} \mathrm{N}$ & $143^{\circ} 22^{\prime} \mathrm{E}$ & $23^{\circ}$ & $23^{\circ}$ & $72 \%$ & 4 & 2 & $\mathrm{G}$ \\
\hline " & 6 & $38^{\circ} 39^{\prime} \mathrm{N}$ & $147^{\circ} 39^{\prime} \mathrm{E}$ & $18^{\circ}$ & $19^{\circ}$ & 91 & 5 & 5 & $\mathrm{O}$ \\
\hline " & 7 & $41^{\circ} 00^{\prime} \mathrm{N}$ & $153^{\circ} 24^{\prime} \mathrm{E}$ & $22^{\circ}$ & $20^{\circ}$ & 87 & 6 & 5 & $\mathrm{G}$ \\
\hline$"$ & 8 & $43^{\circ} 18^{\prime} \mathrm{N}$ & $159^{\circ} 42^{\prime} \mathrm{E}$ & $20^{\circ}$ & $17^{\circ}$ & 82 & 2 & 2 & $O-F$ \\
\hline$" \prime$ & 9 & $45^{\circ} 08^{\prime} \mathrm{N}$ & $166^{\circ} 23^{\prime} \mathrm{E}$ & $17^{\circ}$ & $13^{\circ}$ & 90 & 3 & 3 & $\mathrm{~F}$ \\
\hline " & 10 & $\mathrm{E} 46^{\circ} 20^{\prime} \mathrm{N}$ & $173^{\circ} 45^{\prime} \mathrm{E}$ & $18^{\circ}$ & $13^{\circ}$ & 82 & 3 & 3 & $\mathrm{O}$ \\
\hline " & $" \prime$ & $\mathrm{W} 47^{\circ} 33^{\prime} \mathrm{N}$ & $178^{\circ} 35^{\prime} \mathrm{W}$ & $15^{\circ}$ & $12^{\circ}$ & 85 & 4 & 4 & $\mathrm{O}$ \\
\hline$"$ & 11 & $47^{\circ} 52^{\prime} \mathrm{N}$ & $170^{\circ} 52^{\prime} \mathrm{W}$ & $15^{\circ}$ & $11^{\circ}$ & 85 & 4 & 4 & $\mathrm{O}$ \\
\hline " & 12 & $47^{\circ} 57^{\prime} \mathrm{N}$ & $163^{\circ} 17^{\prime} \mathrm{W}$ & $12^{\circ}$ & $11^{\circ}$ & 83 & 4 & 4 & $\mathrm{O}$ \\
\hline$" \prime$ & 13 & $47^{\circ} 14^{\prime} \mathrm{N}$ & $155^{\circ} 38^{\prime} \mathrm{W}$ & $15^{\circ}$ & $12^{\circ}$ & 90 & 4 & 4 & $\mathrm{O}$ \\
\hline$" \prime$ & 14 & $46^{\circ} 17^{\prime} \mathrm{N}$ & $147^{\circ} 58^{\prime} \mathrm{W}$ & $18^{\circ}$ & $14^{\circ}$ & 86 & 4 & 4 & $\mathrm{O}$ \\
\hline " & 15 & $44^{\circ} 17^{\prime} \mathrm{N}$ & $141^{\circ} 04^{\prime} \mathrm{W}$ & $16^{\circ}$ & $17^{\circ}$ & 85 & 4 & 4 & $\mathrm{O}$ \\
\hline " & 16 & $42^{\circ} 25^{\prime} \mathrm{N}$ & $134^{\circ} 34^{\prime} \mathrm{W}$ & $18^{\circ}$ & $17^{\circ}$ & 72 & 4 & 4 & $\mathrm{O}$ \\
\hline " & 17 & $40^{\circ} 20^{\prime} \mathrm{N}$ & $128^{\circ} 17^{\prime} \mathrm{W}$ & $18^{\circ}$ & $17^{\circ}$ & 68 & 4 & 5 & G \\
\hline
\end{tabular}

Table 2. Noon positions and noon air and water temperatures, 1961

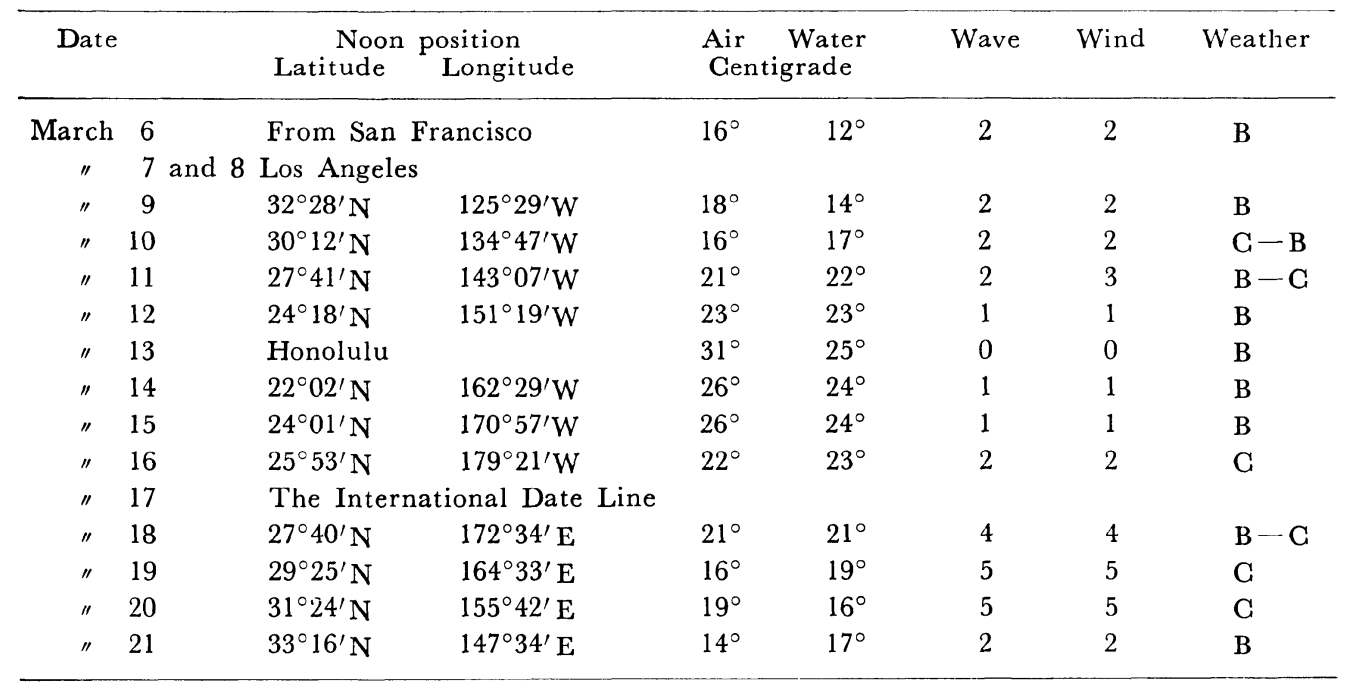

were made in the last three days during my returning trip in 1961. Similar results were also reported by Yocom (1947) and Miller (1942).

\section{Distribution}

Positions of the boat, and various meteorological data in 1959 were shown in Table 1. The range of air temperature is from $15^{\circ} \mathrm{C}$ to $23^{\circ} \mathrm{C}$, whereas water temperature shows from $11^{\circ} \mathrm{C}$ to $23^{\circ} \mathrm{C}$ which has wider range than the air temperature. The scales of wave and wind, show the same trend as air and water temperatures through 
the trip. Table 2 shows the noon positions and other meteorological data of returning trip 1961 in the same manner as in 1959. In general, temperatures of air and water are comparatively higher than the first trip. Range of air temperature varies from $14^{\circ} \mathrm{C}$ to $26^{\circ} \mathrm{C}$ and water temperature from $12^{\circ} \mathrm{C}$ to $25^{\circ} \mathrm{C}$. Wind and wave as well as the weather were milder than the first trip. Numbers of the Black-foots and the Laysan Albatross for 10 to 15 minutes observations are shown in Table 3 and 4. The largest numbers of the Black-foots in 1959 were on August 13, whereas none of birds was observed on the ninth in the same trip. This was probably because of deep fog. The largest population of the Black-foots during my trips was seen on March 15 near Hawaiian Islands and Midway, and only one individual was seen on March 21 near Yokohama. In general, the distributional pattern in March 1961 is similar to the data obtained by Kuroda, Sr. in March 1928 in his voyage from Yokohama to San Francisco via Hawaii. It seems that the Blackfoots in both trips are almost evenly distributed throughout the North Pacific Waters, but slightly larger in eastern side of the Pacific compared with the western side in these two crossings.

It is worthy to find some factors which may influence upon concentrations of the Black-foots. Miller (1940) found the Black-foots concentrated at the continental shelf which produced cold and turbulant surface waters rich in nutrient and zooplankton. He discovered the large numbers of Albatrosses in the east central water mass. He suggested that concentrations of Black-foots are confined to low temperature waters, rich in nutrients and of high biotic productivity. Miller (1940, '42) and Thompson (1951) stated that greater numbers of Black-foots are confined to low temperature waters. Kuroda, Jr. (1955) found that the distribution of most pelagic birds was correlated primarily with water temperature, to a lesser extent with air temperature and least of all with wind direction and velocity. He (1960) observed Black-foots more abundantly in warmer current than Laysan Albatross, and added, among many other pelagic birds, that both Albatrosses fall into cold water group. Hamilton (1958) and Konishi (personal communication, 1960) found greater numbers of Black-foots accompanied the ship to within 200 miles off from Seattle. Unfortunately, I was not able to observe such greater numbers in my trips, but fairly good numbers of this species were found only several miles off from San Francisco in March 1961.

I examined a correlation between sea water temperature and Albatross numbers (Table 5). The largest number of Black-foots in 1959 was found between $20^{\circ} \mathrm{C}$ and $21^{\circ} \mathrm{C}$ of water temperature. Whereas in 1961 (Table 6), the largest number of birds falls into $24^{\circ} \mathrm{C}$ and $25^{\circ} \mathrm{C}$ of water temperature. Thus my data of two crossings show different results respectively. Wilhoft (1961) examined a correlation between Black-foot numbers and water temperature based on the studies of Kuroda, Jr. 
昭和 38 年 (1963) 6 月 Black-footed Albatross in the North Pacific.

Table 3. Number of individuals seen during observations (1)

\begin{tabular}{|c|c|c|c|c|c|c|c|c|c|c|c|c|c|c|c|c|}
\hline Species & & & 6 & 7 & 8 & 9 & $10 \mathrm{E}$ & $\begin{array}{c}\text { Date } \\
\text { 10W }\end{array}$ & in $\mathrm{A}$ & $\begin{array}{l}\text { Augu } \\
12\end{array}$ & st 13 & $\begin{array}{c}59 \\
14\end{array}$ & 15 & 16 & 17 & Total \\
\hline \multirow{2}{*}{ Diomedea nigripes } & 8 & $\mathrm{AM}$ & 0 & 5 & 2 & 0 & 6 & 2 & 4 & 5 & 11 & 1 & 4 & 9 & 3 & 52 \\
\hline & 12 & $\mathbf{P M}$ & 3 & 6 & 1 & 0 & 5 & 2 & 4 & 5 & 9 & 4 & 5 & 7 & 4 & 55 \\
\hline \multirow[t]{2}{*}{ Diomedea immutabilis } & 8 & $\mathrm{AM}$ & 0 & 0 & 0 & 0 & 1 & 0 & 0 & 0 & 1 & 0 & 0 & 0 & 0 & 2 \\
\hline & 12 & P M & 0 & 1 & 0 & 0 & 0 & 0 & 0 & 1 & 0 & 0 & 0 & 0 & 0 & 2 \\
\hline
\end{tabular}

Table 4. Number of individuals seen during observations (2)

\begin{tabular}{|c|c|c|c|c|c|c|c|c|c|c|c|c|c|c|c|c|}
\hline Species & & & 6 & 9 & 10 & 11 & 12 & ${ }_{13}$ & $\begin{array}{r}\text { ate } \\
14\end{array}$ & $\underset{15}{\text { in } N}$ & $\begin{array}{r}\text { March } \\
16 \mathrm{~W}\end{array}$ & $\begin{array}{c}1961 \\
18 \mathrm{E}\end{array}$ & 19 & 20 & 21 & Total \\
\hline \multirow[t]{3}{*}{ Diomedea nigripes } & 8 & $\mathrm{AM}$ & - & 13 & 3 & 3 & 3 & 5 & 9 & 11 & 3 & 2 & 3 & 1 & 0 & 56 \\
\hline & 12 & $\mathbf{P M}$ & 0 & 0 & 0 & 0 & 0 & - & 1 & 4 & 2 & 1 & 14 & 0 & 1 & 23 \\
\hline & 16 & $\mathrm{PM}$ & 9 & 3 & 2 & 0 & 7 & - & 11 & 13 & 1 & 2 & 4 & 3 & 0 & 55 \\
\hline \multicolumn{3}{|c|}{ Diomedea immutabilis } & 0 & 0 & 0 & 0 & 0 & 0 & & $\begin{array}{c}1 \\
16 \mathrm{P}\end{array}$ & M) & 0 & 0 & $\begin{array}{c}1 \\
16 \mathrm{P}\end{array}$ & $\begin{array}{l}0 \\
\text { M) }\end{array}$ & 2 \\
\hline
\end{tabular}

Table 5. Gorrelation between sea water temperature and numbers of Black-footed Albatross.

A. August 1959

\begin{tabular}{lrrrrrrr}
\hline Temperature degree C. & $10-11$ & $12-13$ & $14-15$ & $16-17$ & $18-19$ & $20-21$ & $22-23$ \\
Number of days & 2 & 4 & 1 & 4 & 1 & 1 & 1 \\
Albatross numbers per day & 9.0 & 8.7 & 5.0 & 8.7 & 3.0 & 12.0 & 0.0
\end{tabular}

B. March 1961

Temperature degrees G. $\quad 12-13 \quad 14-15 \quad 16--17 \quad 18-19 \quad 20-21 \quad 22-23 \quad 24-25 \quad 26-27$ Number of days

Albatross number per day

$4.5 \quad 5.3$

2
1.0

-2
4.2

1

$-3$

2. 1

8. $3 \quad 7.0$

Table 6. Gorrelation between air temperature and numbers of the Black-footed Albatross.

A. August 1959

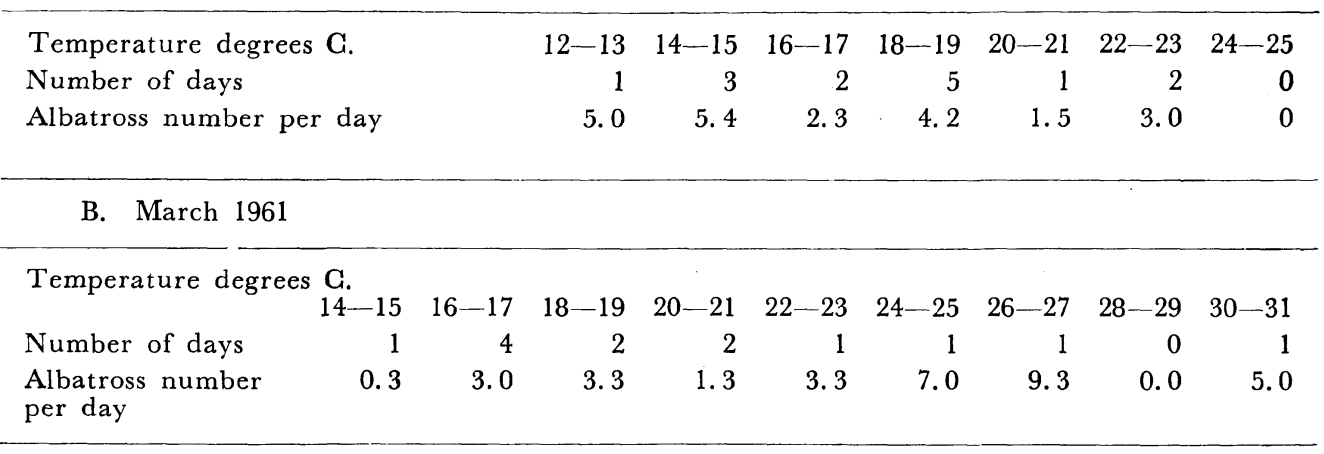


Table 7. Relationship between wind and numbers of the Albatross.

A. August 1959

\begin{tabular}{lrrrrrr}
\hline Wind scale & 1 & 2 & 3 & 4 & 5 & 6 \\
Number of days & 0 & 2 & 2 & 7 & 3 & 0 \\
Albatross per day & 0 & 0.7 & 2.7 & 5.1 & 3.5 & 0 \\
\hline B. March 1961 & & & & & \\
\hline Wind scale & 1 & 2 & 3 & 4 & 5 \\
Number of days & 5 & 5 & 1 & 2 & 0 \\
Albatross per day & 6.0 & 1.9 & 1.7 & 4.4 & 0 \\
\hline
\end{tabular}

Table 8. Relationship between wave and the number of the Black-footed Albatross.

A. August 1959

\begin{tabular}{lrrrrrr}
\hline Wave scale & 1 & 2 & 3 & 4 & 5 & 6 \\
Number of days & 0 & 1 & 2 & 9 & 0 & 2 \\
Albatross per day & 0 & 1.5 & 2.7 & 4.4 & 0 & 3.5 \\
\hline B. March 1961 & & & & & & \\
\hline Wave scale & 1 & 2 & 3 & 4 & 5 \\
Number of days & 5 & 4 & 1 & 2 & 1 & \\
Albatross per day & 6.0 & 1.2 & 4.5 & 1.7 & 7.0 \\
\hline
\end{tabular}

(1955) and Hamilton (1958) and his own. He suggested that concetrations occur in a wide range of water temperature from $11^{\circ} \mathrm{C}$ to $29^{\circ} \mathrm{C}$. Yocom (1947) found a more constant distribution in the warm and cold water, whereas Kuroda, Jr. (1955) found the greatest numbers of this species in the warm waters off Japan $\left(14^{\circ} \mathrm{C} \sim 17^{\circ} \mathrm{C}\right)$. Hamilton (1958) and Wilhoft (1961) interpret Kuroda's view and suggested that the concentrations are not actually confined to water of low or high temperature. The data of this paper are variable from low to high temperature, accordingly it seems that the numbers of Black-foots are also not affected directly by water of low or high temperatures. I rather regret that my data do not show clear evidence to find any factors which may influence upon Albatross concentrations. However, I asume that concentrations of birds are probably related to their feeding habitat, as birds concentrate in the heavily fished waters off the coast of central Japan, near the coast of northern Japan as was suggested by Kuroda, Jr. (1955, '60) and off Seattle (Hamilton 1958 and Konishi 1960). From the facts that the results of workers on concentrations of the Albatross in different seasons and some examples of seasonal flight in Steller's Albatross (Yamashina, personal communication, 1962), I would think that migration of this species should be investigated on the factors which may influence upon concentrations of the Albatrosses. 


\section{Acknowledgement}

I would like to express my cordial thanks to Dr. Nagahisa Kuroda for his invaluable suggestions and for reading the manuscript. Thanks are also due to Drs. William J. Hamilton and Masakazu Konishi for their valuable suggestions for undertaking these observations and to Dr. Yoshimaro Yamashina for his helpful instructions on general problems in these investigations. I am also indebted to the College Women's Glub of Tokyo for offering me a grant on one way passage to the west coast of the United States.

\section{Summary}

The observations on the Black-footed Albatross during the two crossings in the Pacific Waters both in August 1959 and in March 1961 were reported. In general, the Albatross numbers in nonbreeding concentrations are almost evenly distributed throughout the North Pacifie Ocean. It seems however, that concentrations of this species on the eastern side of the Pacific Waters from the International Date Line is slightly heavier than the western side in these trips. Some factors which may influence upon concentrations of the Black-footed Albatross were investigated. However, no adequate correlation was found between Albatross numbers and sea water or air temperature, nor other meteorological data. Brief observation on the Laysan Albatross was described. The data suggest that further investigations on feeding habits and migration of the Albatross will be necessary to evaluate the factors which may influence upon their concetrations.

\section{Literature cited}

Arnold, L. W. 1948. Obserbations on population of North Pacific pelagic birds. Auk 65 : $553 \sim 8$.

Aronoff, A. E. 1960. Some observations on bird of Torishima. Tori $15: 269-279$.

Hamilton, W.J. 1958. Pelagic birds observed on a North Pacific crossing. Gondor 60:159 $\sim 164$.

King, J.E. and Pyle, R.L. 1957. Observations on sea birds in the tropical Pacific. Gondor $59: 27 \sim 39$.

Kuroda, N. 1928. Albatrosses in the Pacific Ocean (In Japanese). Tori $6: 43 \sim 45$.

Kuroda, N.h. 1955. Observations on pelagic birds of the northwest Pacific. Condor $57: 290$ $\sim 300$.

Kuroda, N.h. 1960a. Analysis of bird distribution in the northwest Pacific Ocean. Pacific Science $14: 55 \sim 67$.

Kuroda, N.h. 1960b. Observation diary of sea-birds and mammals during research cruise to the NW Pacifi: (In Japanese). Japan Wildlife Bull. $17: 307 \sim 334$. 
Miller, L. 1940. Observations on the Black-footed Albatross. Gondor $42: 229 \sim 238$.

Miller, L. 1942. Some tagging experiments with Black-footed Abatrosses. Gondor 44:3 9.

Thompson, D.Q. 1951. Notes on distribution of North Pacific albatross. Auk $68: 227 \sim 235$.

Wilhoft, D.G. 1961. Birds observed during two crossings of the Pacific Ocean. Condor 63 : $257 \sim 262$.

Yocom, G. 1947. Notes on behavior and abundance of the Black-footed Albatrosses in the Pacific water off the continental North American shores. Auk $64: 507 \sim 523$.

要 約＼cjkstart筆者は1959年 8 月及び1961年 3 月再度船舶で北太平洋を横断する機会を得，クロ アシアホウドリの観察を行う事が出来たのでそれらの結果について報告を行った。

毎日 8 時と12時及び州路には更に16時に，それぞれ約10分から15分間アホウドリの観察を行 い，同時に毎日の気象データーを記録した。クロアシアホウドリは大陸沿岸を除く外は，一般 に洋上広く分布しており，船を発見するや船尾に飛来し，凡そ十数分乃至数十分間船を追い 2，3 時間以上船尾に追従するものはほとんどないようである。船員の捨てた残飯にはすかさ ず飛びつきこれをあさる所から, 明らかに採慨の為に船を追うものと考えられる。二航海在通 じた観察によるとクロアシアホウドリの分布状態は日付変更線より東側の方がやや多いように 見受けられた。又コアホウドリはその数は前者に比してはるかに少なく，36日の航海を通じ数 羽観察されたのみであり，然も何時も1 羽のみで飛翔し船尾を追う事は殆どなかった。クロア シアホウドリの分布数と気象データーとの間に何か相関関係があるかが大きな疑問であった が，観察の結果特に目立った相関関係はみられなかった。然し中でも気温との間に何らかの関 係がありそれに続いて水温が上げられるようである。アホウドリの分布を決定する要因を調べ る為には先づ船から観察される鳥数は自然分布密度からみて遙かに低い事を考察しなければな らないし, 食慨となる微生物や魚類等の分布も更に調べる必要があろう。又従来あまり考虑さ れていなかった，アホウドリの四季に於ける渡りについて更に研究をしなければならないと考 えている。 